\title{
APLIKASI MODEL WARD AND PEPPARD DALAM PERENCANAAN STRATEJIK SISTEM DAN TEKNOLOGI INFORMASI PERUSAHAAN
}

\author{
Muksin Wijaya \\ Sekolah Tinggi Manajemen Informatika dan Komputer LIKMI \\ Jl. Ir. Juanda 96 Bandung 40132 \\ muksin.wj@gmail.com
}

\begin{abstract}
ABSTRAK
Di dalam suatu organisasi atau perusahaan banyak terjadi dinamika perubahan strategis baik eksternal maupun internal. Kemampuan untuk tetap eksis serta mampu bersaing dalam era globalisasi sangat diperlukan dalam menghadapi tantangan dan memanfaatkan peluang yang ada semaksimal mungkin agar menjadi suatu keunggulan kompetitif. Dalam menyusun strategi bisnis harus terintegrasi dengan strategi bisnis perusahaan.

Untuk merencanakan suatu strategi terlebih dahulu perlu diketahui kondisi lingkungan, arah dan tujuan bisnis perusahaan, informasi apa yang dibutuhkan, peluang dan hambatan bisnis yang dihadapi serta alternatif solusinya. Setelah mengetahui kondisi lingkungan, arah dan tujuan dari kegiatan bisnis perusahaan, maka dapat dievaluasi sistem apa yang sesuai dengan kebutuhan dan mendukung strategi bisnis perusahaan dalam pencapaian visi dan misi perusahaan. Model strategis yang akan dibangun berdasarkan metode analisis Ward and Peppard bisa menghasilkan suatu rencana stratjik bagi masa depan perusahaan.
\end{abstract}

Kata Kunci : Perencanaan Stratejik, Ward and Peppard Model

\section{PERENCANAAN STRATEJIK}

Strategi pada dasarnya adalah suatu bentuk kegiatan atau cara pendekatan yang diterapkan manajer untuk memuaskan pelanggannya, membentuk posisi pasar yang menarik dan mencapai sasaran oganisasi.

Definisi strategi sistem informasi menurut pearlson dan Saunders (Pearlson, 2004:30) adalah rencana sebuah organisasi untuk menyediakan layanan informasi. Strategi sistem informasi ditempatkan dalam satu kesatuan yang disebut segitiga strategi SI. Strategi sistem informasi dapat dilihat pada Gambar 1. 


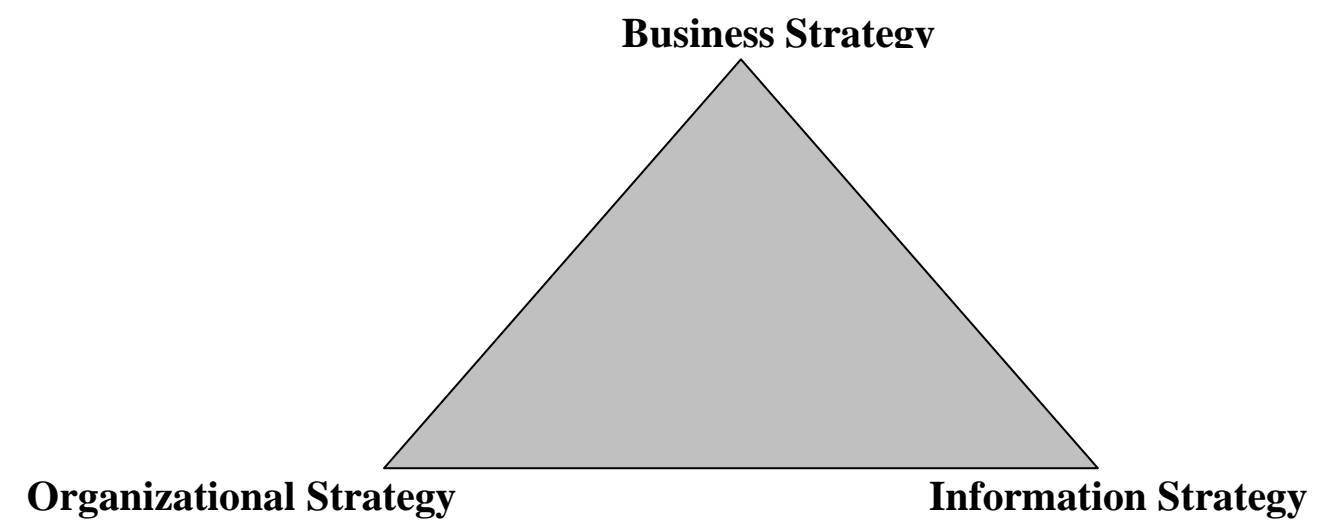

Gambar 1. Segitiga Strategi Sistem Informasi

Dalam Gambar 1 dapat dijelaskan bahwa strategi sistem informasi terdiri dari strategi bisnis, strategi organisasi dan strategi informasi. Ketiga strategi ini harus menampilkan suatu keselarasan. Strategi SI memiliki komponen yang terdiri dari hardware, software, networking, dan data serta dihubungkan dengan pertanyaan what, who dan where.

Menurut Hartono (2006:295), strategi organisasi terdiri dari serangkaian kegiatankegiatan kompetitif dan pendekatan-pendekatan bisnis yang diterapkan manajemen dalam menjalanan kegiatan operasional organisasinya. Strategi yang tepat untuk suatu organisasi atau perusahaan yaitu:

a. Organisasi atau perusahaan perlu secara aktif membentuk kegiatan - kegiatan. Suatu strategi perusahaan menyediakan suatu cara atau pendekatan bagi perusahaan untuk dapat melakukan menyediakan peta jalan (roadmap) untuk beroperasi, petunjuk petunjuk untuk melakukan bisnis, perencanaan untuk membangun pelayanan yang baik berkelanjutan melebihi pesaing - pesaingnya.

b. Untuk menyatukan keputusan, inisiasi kegiatan yang dilakukan oleh departemen, manajer dan karyawan di dalam organisasi kedalam suatu perencanaan yang terkoordinasi dan teritegrasi di level korporasi.

Menurut Umar (2001:158), mendefinisikan strategis sebagai suatu proses penentuan rencana para pemimpin puncak yang befokus pada tujuan jangka panjang organisasi, disertai penyusunan suatu cara atau upaya bagaimana tujuan tersebut dapat dicapai.

Perencanaan strategis adalah proses yang partisipatif, sistematis, berkelanjutan yang membantu sebuah organisasi untuk memusatkan semua kegiatan untuk pencapaian misinya dan memastikan bahwa semua staff nya bekerja untuk pencapaian sasaran yang sama. Perencanaan mengarahkan antisipasi tindakan yang harus diambil untuk menciptakan kondisi yang diinginkan. Definisi kondisi yang diinginkan, demikian pula pemilihan arah serta

\section{METODE PERENCANAAN STRATEJIK SISTEM DAN TEKNOLOGI INFORMASI DENGAN ANALISIS WARD AND PEPPARD}

Model perencanaan Ward and Peppard ini dimulai dari investasi teknologi informasi yang sudah ada dan kurang bermanfaat dalam menunjang visi dan misi perusahaan dan memanfaatkan teknologi informasi terbaru yang dapat meningkatkan keunggulan kompetitif dari perusahaan atau organisasi. Perencanaan strategis selain memanfaatkan teknologi juga harus berdasarkan kebutuhan bisnis.

Berikut model strategis Ward and Peppard. 


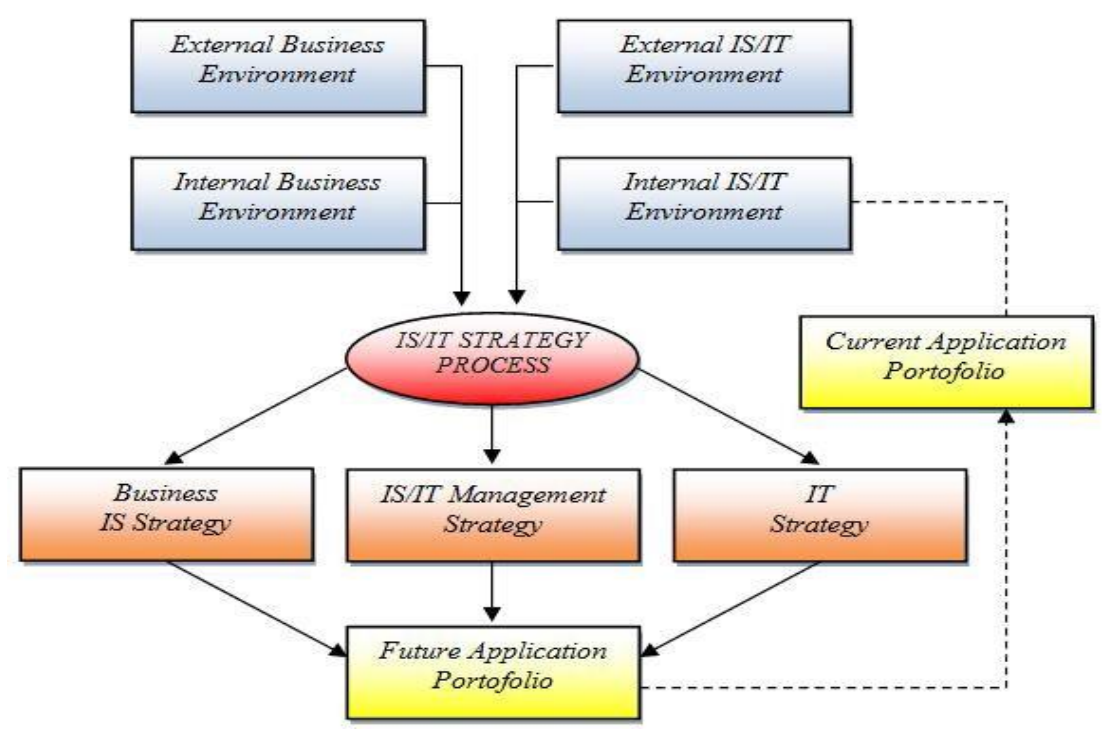

Gambar 2. Model Strategis Ward and Peppard

(Ward \& Peppard 2003:154)

Pada Gambar 2 tentang model strategis Ward and Peppard dalam perencanaan sistem dan teknlogi informasi bagian-bagian penting dalam penyusunan IS/IT Strategic Plan. Tahapan pada Ward and Peppard terdiri dari tahapan masukan dan tahapan keluaran. Kerangka kerja dalam menyusun perencanaan strategik sistem informasi berdasarkan metodologi ini, memerlukan analisis terhadap empat masukan (input), sebagai berikut:

a. Lingkungan Bisnis Internal (The internal business environment)

Strategi bisnis yang dimiliki organisasi, objek yang terlibat, sumber-sumber, proses, dan tradisi atau kebiasaan juga hasil bisnis. Lingkungan internal dipengaruhi oleh beberapa faktor yaitu tenaga kerja (man), modal (money), material atau bahan baku (material), peralatan atau perlengkapan produksi (machine), metode (methods). Lingkungan internal ini biasanya digunakan untuk menentukan Strength (kekuatan) perusahaan, dan juga mengetahui Weakness (kelemahan) perusahaan.

Lingkungan internal adalah faktor-faktor yang berada dalam kegiatan produksi dan langsung mempengaruhi hasil produksi. Contoh dari lingkungan internal ini yaitu:

1) Tenaga kerja

2) Peralatan dan mesin

3) Permodalan (pemilik, investor, pengelolaan dana)

4) Bahan mentah, bahan setengah jadi, pergudangan

5) Sistem informasi dan administrasi sebagai acuan pengambilan keputusan.

Faktor lingkungan terdiri dari:

1) Lingkungan perekonomian yang erat berhubungan dengan pasar dimana diadakan penjualan dan pembelian barang dan jasa.

2) Lingkungan seperti politik, pemerintah, hukum, dan militer yang mengatur kegiatan perusahaan.

3) Keadaan sosial meliputi berbagai golongan penduduk dengan sikap kepercayaan, tingkah laku yang dicerminkan dalam lembaga sosial yang ada. Dari faktor lingkungan ini digolongkan lagi menjadi beberapa faktor yaitu:

a) Tanah dan alam sekitar

Tanah dan sumber alam merupakan salah satu faktor penting untuk kegiatan perusahaan. 
b) Ilmu pengetahuan dan seni

Ilmu pengetahuan menunjukkan metode, manajemen kepada pimpinan dalam mengelola perusahaan. Penerapan ilmu pengetahuan dalam dunia perusahaan akan dapat membantu menggali ilmu pengetahuan lebih lanjut.

c) Pemerintah dan hukum

Aspek positif dari pemerintah akan dibutuhkan oleh perusahaan ialah perlindungan terhadap hak milik, pemeliharaan tata hukum, dan keamanan, serta penggunaan keuangan, tetapi pemerintah perlu mengadakan pembatasan dengan mengadakan pemungutan pajak dan tarif.

d) Uang, kredit, kapital

Uang kredit merupakan darah bagi kehidupan perusahaan. Apabila uang, kredit, dan kapital ini lambat akan menghambat jalannya perusahaan. Sebaliknya, jika jumlah yang terlampau banyak akan mengganggu perusahaan. Uang sebagai alat pembayaran, termasuk kredit didalamanya. Mengenai kapital perusahaan tidak akan dapat menjalanka fungsinya tanpa kapital.dana kapital ini dalam bentuk terkumpulnya uang atau kredit yang diinfestasikan dalam perusahaan.

e) Tersedianya tenaga kerja

f) Tenaga kerja dalam perusahaan pada umumnya bersatu dalam bentuk serikat kerja. Berhasilnya perusahaan tergantung pada tingkat ketrampilan, kesehatan, dan sikap dari tenaga kerja. Hal ini sangat tergantung pada system pendidika, standar hidup, dan inisiatif dari masyarakat.

g) Sikap konsumen

Usaha perusahaan untuk mengurangi resiko dalam memenuhi kebutuhan masyarakat dengan memperhatikan sikap konsumen dan publik.

h) Kepercayaan dan agama

Mempengaruhi tingkah laku manusia serta etika masyarakat, hal ini mempengaruhi kebijaksanaan perusahaan yang diambil oleh manajer. Standar etika ini harus diikuti oleh perusahaan.

i) Hubungan internasional

Hubungan ini meliputi penyediaan sumber ekonomi, bahan perdagangan dan politik mungkin tidak terbatas pada bahan dasar, tetapi juga berupa tenaga kerja terdidik yang didatangkan dari luar negeri.

b. Lingkungan Bisnis Eksternal (The external business enviroment)

Kondisi ekonomi, industri dan kompetisi bisnis di luar organisasi. Dan juga mencakup sisi politik, ekonomi, sosial, teknologi, industri, dan iklim kompetisi dimana perusahaan tersebut beroperasi.

Lingkungan eksternal dibagi menjadi dua yaitu lingkungan mikro dan lingkungan makro. Lingkungan mikro, dimana perusahaan dapat melakukan aksi reaksi terhadap faktorfaktor penentu Opportunity (peluang pasar) dan juga Threat (ancaman dari luar). Adapun faktor-faktor yang mempengaruhi lingkungan mikro yaitu pemerintah, pemegang saham (stakeholder), kreditor, pesaing, publik, perantara, pemasok, konsumen.

Lingkungan eksternal perusahaan yang berpengaruh tidak langsung terhadap kegiatan perusahaan. Lingkungan eksternal meliputi variabel-variabel di luar organisasi yang dapat berupa tekanan umum dan tren di dalam lingkungan societal ataupun faktorfaktor spesifik yang beroperasi di dalam lingkungan kerja (industri) organisasi. Variabelvariabel eksternal ini terbagi menjadi dua jenis, yaitu ancaman dan peluang, Lingkungan eksternal perusahaan dapat dibedakan menjadi :

1) Lingkungan eksternal makro, adalah lingkungan eksternal yang berpengaruh tidak langsung terhadap kegiatan usaha. 
Contoh :

a) Keadaan alam: SDA, lingkungan

b) Politik dan hankam: kehidupan operasional perusahaan sangat terpengaruh oleh politik dan hankam negara dimana perusahaan berada menciptakan.

c) Hukum

d) Perekonomian

e) Pendidikan dan kebudayaan

f) Sosial dan budaya

g) Kependudukan

h) Hubungan internasional

2) Lingkungan eksternal mikro, adalah lingkungan eksternal yang pengaruh langsung terhadap kegiatan usaha.

Contoh :

a) Pemasok / supplier : yang menunjang kelangsungan operasi perusahaan.

b) Perantara, misalnya distribotur, pengecer yang berperan dalam pendistribusian hasil-hasil produksi ke konsumen.

c) Teknologi: yang berkaitan dengan perkembangan proses kerja, peralatan metode.

d) Pasar, sebagai sasaran dari produk yang dihasilkan perusahaan.

c. Lingkungan SI/TI Internal (The internal IT enviroment)

Kondisi perspektif sistem informasi atau teknologi informasi dalam bisnis,lingkup bisnis, kemampuan, sumber, dan teknologi infrastruktur. Portofolio dari sistem aplikasi yang digunakan, sistem yang masih dibangun, dan keuangan dalam pembangunan.

d. Lingkungan SI/TI Eksternal (The external IT enviroment)

Mencakup era teknologi dan peluang yang ada, dan teknologi yang digunakan oelh pihak lain terutama pesaing dan supplier. Output yang dihasilkan dari perancangan strategik sistem informasi ini menghasilkan tiga keluaran, sebagai berikut:

1) Strategi bisnis sistem informasi (Business IS/IT Strategy)

Setiap unit atau fungsi akan didukung teknologi informasi dan kemampuan bisnis.

2) Strategi manajemen (IS/IT Management Strategy)

Elemen umum yang merupakan strategis yang digunakan dalam organisasi, kepastian dan keamanan yang dibutuhkan.

3) Strategi teknologi informasi (IS/IT Strategy)

Strategi dan keamanan untuk manajemen dari teknologi informasi, dan pakarpakar teknologi informasi.

Hasil akhir dari perencanaan strategik sistem informasi adalah sebuah portofolio aplikasi pada masa yang akan datang (future application portfolio). Setelah diimplementasikan, portofolio ini akan menjadi aplikasi (current application portfolio) yang akan menjadi dasar untuk perbaikan atau pengembangan sistem berikutnya.

Ward and Peppard membedakan antara Sistem Informasi (SI) dengan Teknologi Informasi (TI). Definisi dari Teknologi Informasi (TI) yaitu khusus untuk teknologi, pada dasarnya perangkat keras, perangkat lunak dan jaringan telekomunikasi. Sedangkan untuk strategi sistem informasi yaitu bersangkutan dengan organisasi diperlukan sistem informasi atau kelompok aplikasi. Sedangkan strategi teknologi informasi yaitu berhubungan dengan teknologi, infrastruktur dan ketrampilan spesialis.

Dalam membuat suatu strategic application tidak boleh hanya memfokuskan pada analisis terhadap teknologi saja. Jalur yang efektif untuk menghasilkan keuntungan dari SI /TI adalah dengan mengkonsentrasikan pada pemikiran tentang bisnis, yaitu dengan 
menganalisis masalah bisnis yang ada dan perubahan lingkungannya, menyadari bahwa SI/TI adalah hanya salah satu bentuk solusi yang ditawarkan, karena ia menemukan bahwa strategi SI/TI saat ini lebih banyak mengidentifikasikan persoalan teknologi dan terminologi teknikal saja, tetapi sedikit mengidentifikasikan kebutuhan organisasi akan aplikasi dan kebutuhan bisnis. Strategi SI berfokus dalam mengidentifikasikan kebutuhan perusahaan terhadap SI dan strategi TI berfokus dalam mengidentifikasikan kebutuhan perusahaan terhadap TI dan infrastrukturnya.

Dari gambar 2.4 dapat diidentifikasikan dampak potensial, kemudian mengevaluasi informasi dan sistem yang dibutuhkan untuk menentukan tercapainya sistem informasi berdasarkan teknologi. Hubungan antara strategi bisnis, strategi SI, dan strategi TI saling berkaitan satu sama lain yang didasarkan pada misi dan visi perusahaan, lingkungan bisnis internal maupun eksternal serta pengambilan keputusan bisnis. Dan semua itu disatukan menjadi strategi bisnis dengan merencanakan sistem informasi yang tepat serta mendukung strategi bisnis. Tiga hal penting dalam strategi sistem informasi yaitu basis bisnis (Business Based), orientasi permintaan atau pelanggan (Demand Oriented) dan fokus aplikasi (Application Focused).

Menurut Ward and Peppard (2002:40), dalam membuat suatu strategic application tidak hanya memfokuskan pada analisis terhadap teknologi saja. Jalur yang efektif untuk menghasilkan keuntungan dari SI atau TI adalah dengan mengkonsentrasikan pada pemikiran tentang bisnis, yaitu: dengan menganalisis masalah bisnis yang ada dan perubahan lingkungannya, menyadari bahwa SI atau TI adalah hanya salah satu bentuk solusi yang ditawarkan, karena ia menemukan bahwa strategi SI/TI saat ini lebih banyak mengidentifikasikan persoalan teknologi dan terminologi teknikal saja, tetapi sedikit mengidentifikasikan kebutuhan organisasi akan aplikasi dan kebutuhan bisnis. Strategi SI fokus dalam mengidentifikasikan kebutuhan perusahaan terhadap sistem informasi dan strategi TI fokus dalam mengidentifikasikan kebutuhan perusahaan terhadap teknologi informasi dan infrastrukturnya.

Hubungan antara strategi bisnis, strategi SI, dan strategi TI dalam suatu pendekatan untuk menyusun strategi sistem dan teknologi informasi yang terintegrasi dengan strategi bisnis perusahaan. Untuk merencanakan suatu strategi SI/TI terlebih dahulu perlu diketahui kondisi lingkungan, arah dan tujuan bisnis perusahaan, informasi apa yang dibutuhkan, peluang dan hambatan bisnis yang dihadapi serta alternatif solusinya. Setelah mengetahui kondisi lingkungan, arah dan tujuan dari kegiatan bisnis perusahaan, maka kita dapat mengevaluasi sistem apa yang sesuai dengan kebutuhan dan mendukung strategi bisnis perusahaan dalam pencapaian visi dan misi perusahaan, selanjutnya untuk menghasilkan suatu sistem informasi yang strategis bagi perusahaan, perlu dilakukan penyeleksian dan pemilihan secara tepat teknologi apa yang paling sesuai untuk digunakan dalam menunjang sistem informasi tersebut.

Perencanaan strategi sistem informasi harus sepenuhnya menyatu dengan perencanaan bisnis perusahaan. Intergrasi akan tercapai pada saat perusahaan melakukan alignment antara perencanaan bisnis dan perencanaan sistem informasi. Perencanaan sistem informasi dapat dimulai dari visi bisnis dari perusahaan yang di break down ke dalam sasaran-sasaran yang dikategorikan dalam empat dimensi seperti yang diusulkan oleh Kaplan dan Norton dalam bentuk balanced score card.

Penyelarasan stategi sistem informasi dan sasaran dari organisasi akan berdampak pada strategi organisasi kedepannya. Ada dua pandangan untuk melihat hubungan antara TI dengan bisnis perusahaan. Ketika driver dari strategi sistem informasi adalah bisnis (business), dimana portofolio aplikasi dirancang untuk mendukung proses bisnis saat ini dan potensial dari TI tidak diikuti secara penuh. Pada pandangan lainnya, jika driver dari strategi sistem informasi dari sisi kemajuan 
TI (e-business), dimana risiko yang dapat terjadi adalah investasi pada unprofitable applications. Dan hal lain yang mungkin digunakan adalah pendekatan yang memungkinkan peluang bisnis dan kemajuan teknologi dari TI dipertimbangkan secara bersamaan untuk memungkinkan timbulnya inovasi, tetapi tentunya realistis dengan perencanaan.

Perubahan lingkungan SI/TI sangat cepat sekali, khususnya dalam hal pengembangan teknologi, hal ini membuat perusahaan sulit untuk menetapkan proses perencanaan yang standard dalam konteks perencanaan sistem informasi. Oleh karena itu perencanaan sistem informasi dalam kaitannya dengan proses perencanaan harus dirancang dan diselaraskan dengan perencanaan bisnis atau organisasi.

Arti penting dan kegunaan integrasi Business Planning Information System telah dibuktikan secara empiris dapat meningkatkan kontribusi sistem informasi terhadap kinerja organisasi. Sayangnya, seringkali nilai investasi di bidang sistem informasi tidak dapat direalisasikan secara penuh sebagai akibat dari kurang padu dan padannya penyelarasan strategik antara strategi bisnis dan strategi sistem informasi dalam suatu organisasi. Dengan demikian, peningkatan kinerja maupun keunggulan kompetitif akan sulit tercapai. Untuk itu, diperlukan model penyelarasan strategik antara strategi bisnis dan strategi sistem atau teknologi informasi dalam meningkatkan kinerja organisasi.

\section{PENYELARASAN STRATEJIK}

Strategi bisnis merupakan pilihan-pilihan utama perusahaan tersebut dalam area bisnisnya. Tingkat kepentingan strategi bisnis dipengaruhi oleh kebijakan strategis perusahaan pada keputusan make or buy, yakni kemitraan dan aliansi. Kemitraan diterjemahkan sebagai seberapa tinggi ketergantungan pengembangan bisnis perusahaan pada mitra strategisnya. Sementara aliansi dijabarkan menurut tingkat ketergantungan pengembangan bisnis perusahaan pada aktivitas alih daya (outsourcing). Penyelarasan stratejik (strategic aligment) sendiri dari kata "penyelarasan" (aligment) dan "strategi" (strategy).

Penyelarasan dapat dicapai ketika strategi sistem atau teknologi informasi perusahaan mengacu dari strategi organisasi, meliputi:

a. Content linkage yang mengacu pada konsistensi antara rencana bisnis dan rencana sistem atau teknologi informasi. Semakin konsisten antara rencana bisnis dan rencana sistem atau teknologi informasi, maka tingkat penyelerasan akan semakin baik sehingga kinerja organisasi akan mengalami peningkatan, begitu pula sebaliknya.

b. Timing linkage mengacu pada apakah rencana sistem atau teknologi informasi dikembangkan setelah, beriringan atau sebelum rencana bisnis dibuat. Dalam hal ini berpegang pada perencanaan, pelaksanaan, penganggaran, pengendalian dan evaluasi. Sistem atau teknologi informasi dapat dikembangkan setelah rencana bisnis jika kebutuhan sistem atau teknologi informasi pada organisasi tidak bersifat mendesak atau penting. Pengembangan rencana sistem atau teknologi informasi dikembangkan secara beriringan dengan rencana bisnis jika kebutuhan tersebut bersifat paralel dan berjalan secara simultan. Dengan kata lain, bila rencana sistem atau teknologi informasi tidak diiringi dengan rencana bisnis atau sebaliknya, maka kinerja organisasi tidak akan mengalami kemajuan, tetapi stagnan bahkan mengalami penurunan. Untuk pengembangan rencana sistem atau teknologi informasi sebelum rencana bisnis, maka kebutuhan sistem atau teknologi informasi bersifat mendesak atau sesuatu yang sangat penting. Ini dapat dikatakan bahwa rencana bisnis tidak akan berjalan atau mengalami hambatan bila rencana sistem atau teknologi informasi tidak dikembangkan terlebih dahulu. Pengembangan rencana sistem atau teknologi informasi dengan rencana 
bisnis, baik setelah, beriringan maupun sebelum pada kedua rencana tersebut perlu diperhatikan juga kemampuan anggaran pada organisasi. Dengan memperhatikan perencanaan dan penganggaran, maka keputusan untuk pelaksanaan rencana tersebut, baik sebelum, beriringan dan setelah dapat berjalan secara optimal.

Penyelarasan strategik (strategic aligment) merupakan konsep yang dikembangkan dan diperoleh dari covariation atribut tingkat kepentingan strategi bisnis dan strategi sistem atau teknologi informasi pada waktu tertentu. Penyelarasan dapat dicapai ketika strategi sistem atau teknologi informasi perusahaan mengacu pada strategi organisasi meliputi content linkage, timing linkage, dan personel linkage serta dengan persepektif business execution, competitive potential, information technology potential, dan service level.

Organisasi yang terlihat baik kinerjanya adalah organisasi dimana ada penyelarasan antara realisasi strategi bisnis dan realisasi strategi sistem informasi. Untuk itu, organisasi perusahaan yang mencapai penyelarasan dapat membangun strategi keuntungan kompetitif yang akan meningkatkan organisasi dengan peningkatan visibilitas, efisiensi, dan profitabilitas pada persaingan dalam perubahan pasar saat ini.

Menurut Jogiyanto (2005:65) terdapat empat macam keselarasan atau integrasi yaitu sebagai berikut ini:

a. Integrasi administratif (administrative integration). Integrasi ini menunjukkan hubungan yang sangat lemah antara perencanaan strategik bisnis dan perencanaan strategik sistem teknologi informasi yang berarti tidak ditemukan usaha yang signifikan dari penggunaan sistem teknologi informasi untuk mendukung rencanarencana bisnis.

b. Integrasi urut satu arah (one way sequential integration). Integrasi ini menunjukkan hubungan integrasi satu arah dilakukan untuk mendukung rencana-rencana bisnis.

c. Integrasi bolak-balik dua arah (two way reciprocal integration). Integrasi ini menunjukkan hubungan integrasi dua arah dilakukan untuk mendukung dan sekaligus mempengaruhi rencana-rencana bisnis

d. Integrasi penuh (full integration). Integrasi ini menunjukkan tidak adanya perbedaan keduanya dilakukan bersamaan di dalam satu perencanaan yang terintegrasi. Dengan demikian, peningkatan kinerja dapat dicapai dan keunggulan kompetitif akan diperoleh sehingga organisasi dapat terus bertumbuh serta mampu bertahan dalam kompetisi.

\section{DAFTAR PUSTAKA}

Ferrel, O.C \& D. Harline, 2005, Marketing Strategy, Sourth Western, Thomson Corporation.

Fidler \& Rogerson, 1996, Strategic Management Support Systems, Pitman Publishing, London

Galliers, R.D. \& Leidner, D.E., 2003, Strategic Information Management, Elsivier Butterwoth Heineman, Burlington.

Jane P.Laudon \& Kenneth C.Laudon, 2017, Management Information Systems, pearson, England.

Leitch, Robert A, 1983, Accounting Infromation Systems, Prentice Hall.

Pearlson, Saunders, 2004, Managing Using Systems Strategic Approach, John Willey \& Sons, Ltd, USA.

Porter, Michael E., 1998, Competitive Advantage - Creating a Sustaining Superior Performance, New York: The Free Press. 
Ward, John \& Peppard, Joe, 2003, Strategic Planning for Information System, Chichester: John Willey \& Sons, Ltd, USA.

Warr, Alan, 1990, Strategic opportunities and Information Systems Management. Cranfield: Bedford MK43 OAL. 